\title{
Trade, transboundary impacts and the implementation of SDG 12
}

\author{
$\operatorname{Rob}_{\text {Amos }}{ }^{1}\left(\mathbb{0} \cdot\right.$ Emily Lydgate $^{1}$
}

Received: 19 January 2019 / Accepted: 21 June 2019 / Published online: 17 July 2019

(c) The Author(s) 2019

\begin{abstract}
The 2015 Sustainable Development Goals (SDGs) were developed to 'transform our world'. Yet critics argue that the concept of sustainable development serves to maintain an unsustainable status quo, or provide a positive gloss on a terminal conflict between its 'pillars': environmental protection, economic growth and social welfare. In this article, we examine this tension with respect to the implementation of SDG 12 in the European Union. SDG 12 calls for responsible consumption and production, which necessitates reconciling, or 'decoupling', economic growth and environmental degradation: the core of sustainable development. Initial examination reveals that the largest implementation gap is among high-consuming countries, including those of the EU, the focus of our article, who are failing to account for transboundary impacts of products consumed domestically. This shortcoming, facilitated by the flexibility of the SDG 'global target, national action' approach, undermines the achievement of other environmental SDGs relating to biodiversity and climate, among others. Yet, as compared to other EU approaches to addressing transboundary environmental harm from trade in existing Free Trade Agreements (FTAs) and Multilateral Environmental Agreements (MEAs), which we examine, the global focus and breadth of SDG 12 offers transformative potential. Ultimately, even if the three pillars of sustainable development are not 'rebalanced' toward environmental conservation, they can provide a construct for examining interactions and trade-offs between goals. Simply taking account of transboundary consumption, as SDG 12 indicators call for, would encourage more effective cooperation to help producing countries address environmental problems that result from production for export through impact assessment and enforcement.
\end{abstract}

Keywords SDGs $\cdot$ SDG $12 \cdot$ Trade $\cdot$ Transboundary $\cdot$ Impact assessment

\section{Introduction}

Despite the growth and increasing interconnectedness of global supply chains, wealthy, high-consuming countries have neglected to account for transboundary impacts of their domestic consumption in the context of SDG 12 on responsible production and consumption (Bertelsmann Stiftung,

Handled by John Thompson, Institute of Development Studies, Rural Futures, United Kingdom.

Rob Amos

r.amos@sussex.ac.uk

Emily Lydgate

e.lydgate@sussex.ac.uk

1 Sussex Sustainability Research Programme, Sussex Law School, Falmer, Brighton BN1 9QE, UK
SDSN 2018). Whilst this transboundary gap has been documented both through academic research (see, e.g. Wiedmann and Lenzen 2018) and in the High-Level Political Forum on Sustainable Development (UN 2017, p 12), analysis of existing approaches to take account of transboundary environmental harm are often siloed into sectoral or jurisdictional contexts. In this article we take stock of some existing approaches in both international and EU public law that aim to mitigate and address transboundary environmental harm that occurs through supply chains. We argue that SDG 12 provides an opportunity which is largely being missed: for governments to address the considerable gaps in these current mechanisms, and to account for these harms more systematically.

The SDG framework has significant limitations. The weak implementation of SDG 12 reflects larger critiques of the term 'sustainable development' as serving to maintain 
the status quo, as we document in the first part of this paper. Achieving the transformation the SDGs explicitly requires Parties to go beyond simply cutting and pasting existing policies. For SDG 12, reporting on transboundary impacts constitutes transformational implementation, as it motivates and informs recognition of the need to redress negative impacts. In so doing it builds upon ongoing in the UN context, through for example the International Resources Panel, but goes further in requiring that governments account for transboundary impacts of domestic consumption systematically.

If implemented fully, the political rather than legal orientation of the SDGs, and their emphasis on reporting and information-sharing, provides an opportunity to move beyond entrenched debates about the 'trade and environment' relationship that have hampered ambitions in existing legal frameworks. For example, in trade fora, notably the WTO, developing countries have expressed concern that the EU and other developed countries impede export by imposing environmental requirements which act as market access barriers (Lydgate 2018). While the concerns raised are legitimate, this debate, with its contentious framing, excessively narrows the scope for a collaborative response to an environmental problem which contains symbiotic benefits and harms for importers (outsourcing environmental harm) and exporters (developing export industries).

Arguably, their prevalence and universal participation mean that the SDGs provide the most promising avenue for addressing the issue of environmental harm through supply chains systematically. International environmental law prohibits transboundary harm, but this concept has been construed narrowly as applying only to harm across physical borders. EU procedural requirements, such as Sustainability Impact Assessment of trade agreements, are promising as an approach to increase synergies between SDGs, but are currently limited in scope and effectiveness. Ultimately, taking SDG 12 seriously will help to build a more compelling case for strengthening the current piecemeal approach.

\section{SDG 12 and the achievement of 'sustainable development'}

Adopted in 2015 with the universal agreement of UN countries, the Sustainable Development Goals (SDGs) comprise the international community's agenda 'for people, planet and prosperity'. They build on work undertaken through the Millennium Development Goals (MDGs), adopted in 2000 in an effort 'to ensure that globalization becomes a positive force for all the world's people' (MDGs 2000, para. 5). As a guide for national and international policymaking until 2030 (United Nations (UN) 2015, the SDGs comprise a programme of 17 goals and 169 sub-targets, covering some of the most pressing environmental, economic and social challenges currently facing the planet.

The SDGs are presented as a plan for 'transforming our world' (United Nations 2015) towards sustainable development. Sustainable development's high-profile role in international environmental conferences and policies has helped to impel its global prevalence as a conceptual structure for environmental problem-solving at many different levels of the policy process. Yet, since its inception as an international law commitment (World Commission on Environment and Development 1987), a large body of academic and policy literature has critiqued the concept of sustainable development for its lack of transformative power. In international environmental law, it is often characterised as having three mutually reinforcing pillars: economic development, social welfare and environmental protection (World Summit on Sustainable Development 2002). Critics have noted that its open-ended nature comfortably reinforces a hierarchical positioning of economic development above its other pillars (Beckermann 1994). Some characterise it as simply too broad to catalyse specific action (Pardy 2005). More radically, it has been described as serving to obscure, and thereby prevent the resolution of, a 'latent collision course' between the pillars it purports to harmonise (Stone 1994, p 977). More recent critiques of the SDGs have noted that they seem to endorse a narrative that environmental and social benefits are consequences of economic growth (Kotzé and French 2018).

These issues are pertinent in debates concerning the contentious relationship between trade and the environment. Trade is an aspect of the economic development pillar of sustainable development, with the underlying assumption being that 'trade liberalization leads to greater prosperity, which creates the resources for better environmental management and social policies' (Lydgate 2012a, p 622). Increased trade may lead to positive environmental payoffs domestically, but unless states implement their domestic trade policies in a manner that is sensitive to their external environmental footprints, the global agenda for sustainable development will be frustrated.

With these critiques in mind, we focus on the implementation of SDG 12 on responsible consumption and production. SDG 12 aims to decouple economic growth from resource use and environmental degradation (UN Statistics Division 2018): an issue at the heart of sustainable development. SDG 12 has one of the greatest implementation gaps for wealthy OECD countries, including those of the EU (Bertelsmann Stiftung, SDSN 2018). One reason for this is that effective implementation requires cooperative global action. Much of the impact of domestic consumption in wealthy countries takes place through the depletion of natural resources in other, often developing, countries (Bertelsmann Stiftung, SDSN 2018). Evidence suggests that 
the consumption/production gap between developed and developing countries is continuing to expand (UNEP, International Resources Panel 2015). Thus, whilst the responsibility for mitigating natural resource depletion, pollution and other negative impacts of producing these goods falls within the jurisdiction of producing countries, disproportionately high levels of consumption in wealthy countries makes them increasingly responsible, in practical if not legal terms, for environmental damage that occurs outside their borders. Yet, concerningly, few developed countries have attempted to take account of transboundary trade impacts. In its SDG 12 reporting, for example, the EU concludes that domestic consumption has reduced, but neglects to account for impacts beyond its borders.

The SDG Knowledge Platform itself celebrates that 'the per capita "material footprint" of developing countries grew from 5 metric tons in 2000 to 9 metric tons in 2017, representing a significant improvement in material standard of living' (SDG Knowledge Platform 2018). This shows that the goal of 'decoupling' has yet to be fully embraced by the international community; increased consumption is correlated with improved quality of life, a clash in the environmental and social welfare 'pillars' of sustainable development. This issue is compounded by transboundary approaches to efficient resource management risk being confrontational rather than cooperative. The peremptory norm of permanent sovereignty over natural resources, enshrined in numerous UN General Assembly Resolutions and MEAs, severely limits the extent to which a state may be challenged if others consider their exploitation of their internal natural resources to be unsustainable. Furthermore, concerns regarding the imposition of trade barriers by the developed world continue to influence how developing countries perceive attempts to condition trade and development on economic considerations (Lydgate 2018).

\section{Implementation: the global target, national action approach}

The SDGs largely adopt a 'global target, national action' (GTNA) approach. This consists of the setting of global targets and then encouraging states to take action nationally to contribute towards the achievement of these. The targets themselves encompass both best endeavours and quantitative commitments. GTNA has notable advantages, particularly in the context of such broadscale holistic policymaking that the SDGs encapsulates. In particular, it does not place any constraints, either by demanding certain actions or proscribing them, on the limited resources of states. They remain free to determine the direction and pace of their economic and social development. This is important in a practical sense; states have very different capacities and priorities and so an overly prescriptive regime would be inappropriate. It is also important legally, as it complies with the sovereignty of the individual nation state, one of the most important peremptory norms of international law (Kokott 2007).

The problem is that there is little evidence to suggest that the GTNA approach works. Its flaws are evident in international conservation law. In response to failure of the states party to the 1992 Convention on Biological Diversity (CBD 1992) to 'achieve by 2010 a significant reduction in the current rate of biodiversity loss' (CBD 2002), a new Strategic Plan for Biodiversity, based on 20 targets to be mostly be achieved by 2020 (the Aichi Targets), was adopted (CBD 2010, Annex).

These are global targets to which national action by states contributes, rather than specific targets for states themselves to achieve. However, a midterm assessment of progress towards the Aichi Targets indicated that although some progress had been made, 'in most cases this progress will not be sufficient to achieve the targets set for 2020' (Secretariat to the Convention on Biological Diversity 2014, p 10). Arguably such efforts have not been made, evidenced by the catalogue of recent reports showing that biodiversity continues to decline (for example, WWF/ZSL 2016 and RBG Kew 2016).

The GTNA approach has since been adopted in other areas of international environmental law. A notable example is the nationally determined contributions (NDCs) of emissions reductions that are the central mechanism in Article 4 of the 2015 Paris Agreement. In short, states set their own emission reduction targets and the combined effect of these is intended to achieve the global target, contained in Article 2 , of limiting the global temperature rise to below $2{ }^{\circ} \mathrm{C}$. This flexibility is a marked departure from the more proscriptive approach taken by the 1997 Kyoto Protocol, which has met with increasing criticism since its adoption (Doelle 2016).

At the time it was negotiated, the Paris Agreement was considered a major success (Bodle et al. 2016). However, it is important not to conflate an agreement that is 'good' because it was endorsed by a majority of states with an agreement that is 'good' because it is sufficiently robust so as to be capable ofachieving its stated objectives. The initial set of NDCs fall far below what is needed to achieve even the $2{ }^{\circ} \mathrm{C}$ goal (Intergovernmental Panel on Climate Change 2018).

The breadth and indicator-driven nature of the SDG s likely serves to push implementing states toward prioritising data-collection and reporting as a means to fulfil their SDG treaty obligations. However, within this context, the ambition of the approach that countries can take varies greatly. On the more ambitious end, countries can use the SDGs to inform and guide national policymaking through the country-specific indicators. Germany has gone further than most 
Table 1 German Federal Government, German Sustainable Development Strategy (2016), 241

\begin{tabular}{|c|c|c|c|}
\hline No. & Indicator field sustainability postulate & Indicators & Targets \\
\hline \multicolumn{4}{|c|}{ SDG 12. Ensure sustainable consumption and production patterns } \\
\hline 12.1.a & $\begin{array}{l}\text { Sustainable consumption } \\
\text { Making consumption environmentally } \\
\text { and socially compatible }\end{array}$ & $\begin{array}{l}\text { Market share of goods certified by independently verified sustainability } \\
\text { labelling schemes (future perspective: market share of products and } \\
\text { services with trustworthy and ambitious eco- and social labels) }\end{array}$ & $34 \%$ by 2030 \\
\hline 12.1.b & & Energy consumption and $\mathrm{CO}_{2}$ emissions from consumption & $\begin{array}{l}\text { Continuous } \\
\text { reduction of } \\
\text { energy con- } \\
\text { sumption }\end{array}$ \\
\hline 12.2 & $\begin{array}{l}\text { Sustainable production } \\
\text { Increasing the proportion of sustainable } \\
\text { production }\end{array}$ & EMAS eco-management & $\begin{array}{l}5000 \text { organisa- } \\
\text { tion locations } \\
\text { by } 2030\end{array}$ \\
\hline
\end{tabular}

in developing a series of indicators and targets pertinent to domestic circumstances to help guide national policymaking. For example (Table 1).

Similar indicators and targets have been developed for the other SDGs as well (German Federal Government 2016, pp 239-242).

Less ambitious is what may be described as a 'cut and paste' approach, with states taking pre-existing policies and superimposing these on top of the SDGs. This can be seen in the UK. The website detailing its SDG implementation provides links to a few government resources relevant to the SDG in question, in many cases the Industrial Strategy. ${ }^{1}$ The Industrial Strategy cuts across a range of sectors and could be an effective means of delivering the holistic approach to policymaking that is necessary if the SDGs are to be achieved. However, that the Strategy does not mention the SDGs at all allows us to question whether it is a serious attempt to deliver the global agenda for sustainable development or just being used by the Government to superficially meet its commitments under the SDGs.

Both approaches must be considered legitimate ways for states to implement the SDGs, whatever their flaws, as states are afforded complete discretion in choosing how to do so. Neither should they be seen as mutually exclusive and states often incorporate elements of each. The UK, for example, may currently only make oblique references to policy documents, but the Office for National Statistics is collating data on the SDG indicators so that they can be used to inform decision-making in the future (Office of National Statistics 2017). However, the targeted approach taken by Germany is clearly preferable in demonstrating that SDGs are transformative, rather than simply an auditing exercise.

\footnotetext{
1 https://www.gov.uk/government/publications/implementing-thesustainable-development-goals/implementing-the-sustainable-devel opment-goals.
}

\section{SDG 12 implementation}

With respect to the approaches outlined above, initial reporting on SDG 12, which calls for 'responsible consumption and production', reveals that 'cut and paste' approaches are prevalent. Most notably, few have developed robust, SDG 12-specific indicators. Thus, the whole systems approach believed critical for the success of the SDGs has yet to be adopted (UNEP, International Resource Panel 2017). SDG 12 sub-indicators call for accounting of 'material footprint, material footprint per capital, material footprint per GDP'. In contrast to calculations of domestic material consumption (DMC), material footprint captures consumption of raw materials in other countries through international supply chains, and is thus essential for understanding transboundary impacts (Wiedmann et al. 2015). A 2018 SDG implementation report card refers to these impacts as 'spillovers' through which wealthy countries are undermining other countries' efforts to achieve the SDGs. It lists SDG 12 as one of two areas in which OECD countries are experiencing the greatest compliance gap, noting that many 'are stagnating or experiencing a degradation...partly driven by the relatively high spillover effects embodied in trade ...' (Bertelsmann Stiftung, SDSN 2018).

It is estimated that two-fifths of global raw materials are extracted solely for exports, with the flow of these materials generally traveling from developing to developed countries (Wiedmann et al. 2015, pp 6272-6273). This means that developed countries are able to outsource environmentally harmful practices to developing countries. A World Resources Institute report on the implementation of SDGs by OECD countries echoed these findings, concluding that:

...gap analyses pointed to problem areas, including recognition that countries' environmental performance cannot be evaluated without examining the impacts created by importing resource-intensive goods (O’Connor 2016, p. 2). 
Despite the importance of spillovers to the successful achievement of SDG 12, accounting for transboundary impacts does not comprise a formal element of countries' SDG 12 strategies. In contrast, the 2017 High-Level Political Forum on Sustainable Development found that reporting on SDG 12 had a domestic focus (United Nations 2017, p. 12). A qualitative review of recent implementation strategies echoes this finding. There are uneven approaches with a number of G20 countries failing to address entirely, or only on a limited basis, the transboundary impacts of domestic consumption (Table 2).

As this table shows, the EU and some Member States are participating in cooperative approaches through high-level institutional fora, MEAs and commitments to development assistance to achieve greener production. These dimensions are also represented in the SDG 12 sub-indicators, which include 'number of parties to international environmental agreements on hazardous waste' (12.4.1) and 'amount of support for developing countries ...for environmentally sound technologies' (12.a.1).

However, they have neglected to employ adequate reporting. The EU strategy calls for 'sustainable and responsible' supply chains. A recent EU statistical analysis claims 'significant progress' in decoupling environmental impacts from economic growth, as DMC has reduced by $16.8 \%$ between 2007 and 2017, but acknowledges that '...DMC does not include 'hidden' raw material flows, which are required to generate imports or exports but are not part of the imported and exported raw materials and products' (Eurostat 2018, $\mathrm{p} 2,4-5)$. Thus, it fails to fulfil the reporting requirements proscribed in SDG 12.

\section{Interactions between SDG 12 and other environmentalSDGs}

The failure to account for transboundary impacts of domestic consumption leads consuming countries to undermine the achievement of other SDGs. There is a growing body of academic literature which documents the environmental impacts of international supply chains (connecting these to the need for a more robust approach to the SDGs, see e.g. Wiedmann and Lenzen 2018). For illustrative purposes, a recent study which traced the supply chains for soy and palm in Germany concluded that the "Germany's total consumption-based demand...is almost twice as large as the direct physical imports listed in conventional trade statistics" and this external area is about $20 \%$ of Germany's domestic cropland (Dawkins et al. 2016). It concluded that the areas which produce soy to be exported from Brazil to Germany are water scarce and German imports are potentially worsening the situation.
Partly driven by demand for biodiesel, which ostensibly fulfils climate change mitigation goals, in Indonesia and Malaysia, forest is being cleared both legally and illegally to sell timber and make way for agricultural land for palm oil plantations. This has greatly reduced numbers of orangutan and other species (Voight et al. 2018). The draining of peat bogs to make way for palm oil, and the burning of virgin forest, has also led to vast amounts of trapped methane and carbon emissions being released into the environment. As a result, Indonesia is now the fifth largest global emitter of greenhouse gases (WRI 2018). Thus, consumption of palm oil in the EU is undermining Indonesia's ability to meet SDG 13, which calls for climate action, as well as SDG 15 on life on land, which requires halting biodiversity loss.

\section{EU approaches to mitigating transboundary environmental harm: surveying the gaps}

Beyond SDG 12, the EU employs a number of approaches, enacted through different fora, to address transboundary environmental impacts of its trade and commercial activities. These include trade restrictions through the imposition of EU environmental regulatory requirements on imported products, obligations to consult on, and prevent harm from, projects whose environmental impacts extend beyond national borders, sustainable development chapters in EU trade agreements and Sustainability Impact Assessment of Free Trade Agreements. As above, we do not document these systemically, but instead choose illustrative examples that highlight gaps and limitations.

\section{Regulatory challenges: a case study}

Whilst the EU requires that imported products meet its own regulatory requirements, its ability to monitor these requirements is more limited than for domestic producers. For example, in its Renewable Energy Directive of 2009, the EU has passed legislation specifically to mitigate problems with biofuels. EU biofuels sustainability criteria require that biofuels are relatively efficient vis-à-vis fossil fuels, and restrict where they can be grown, precluding peatland and highly biodiverse areas (EU 2009).

Despite these requirements, illegal logging activity on high conservation lands has been reported among some of the industry's major producers and suppliers to the EU market, including the Duta Palma group (BBC News 2010) and Korindo (Guardian 2016). The Indonesian Biofuels Development Board claims that new plantations will expand only onto unproductive land, which has been deforested and then abandoned. However, companies have a built-in incentive to deforest land, as they receive more money from selling the timber. The example illustrates that tracing the production 
Table 2 SDG 12: recognition of transboundary impacts of domestic production and consumption in selected G20 countries

\begin{tabular}{|c|c|c|}
\hline Country/region & SDG 12 strategic approach & Domestic and/or transboundary impacts focus \\
\hline European Union & $\begin{array}{l}\text { Mapping of EU policies related to SDG 12: Investment } \\
\text { Plan for Europe, circular economy agenda, food waste, } \\
\text { biodiversity policies and private sector development, } \\
\text { including sustainable and responsible supply chains, pro- } \\
\text { moting transition to agreener economy in partner countries, } \\
\text { implementation of multi-lateral environmental agreements } \\
\text { by developing countries, and rules to combat illegal, unre- } \\
\text { ported and unregulated fishing }\end{array}$ & $\begin{array}{l}\text { Focus on domestic role in achieving SDG 12; international } \\
\text { cooperation; but methodology accounts only for domestic } \\
\text { material consumption ('DMC') }\end{array}$ \\
\hline UK & $\begin{array}{l}\text { Linked to Industrial Strategy, which responds to four 'Grand } \\
\text { Challenges' including clean growth focusing on domestic } \\
\text { construction and transport technology. There is no specific } \\
\text { engagement with SDG } 12\end{array}$ & Domestic focus \\
\hline Germany & $\begin{array}{l}\text { Emphasis on promotion in international forums. Part of } \\
\text { High-Level Support Group (including Sweden, Brazil, } \\
\text { Colombia, Tunisia, Liberia, South Africa, Tanzania, Timor- } \\
\text { Leste) to contribute to "rapid and ambitious implementa- } \\
\text { tion" of SDG goals at national and international level. } \\
\text { Recognition of global responsibility and aiming to support } \\
\text { partner countries with implementation of environmental } \\
\text { and social standards, promotion of technology transfer with } \\
\text { regard to sustainable consumption and production }\end{array}$ & Domestic and international focus \\
\hline France & $\begin{array}{l}\text { International focus for SDGs generally. SDGs mapped onto } \\
\text { existing public policies. SDG } 12 \text { focus on circular economy } \\
\text { and responsible consumption and production. Interna- } \\
\text { tional focus on 'social entrepreneurship' and 'solidarity } \\
\text { economy' programmes, e.g. agroecology in Madagascar }\end{array}$ & $\begin{array}{l}\text { Predominantly domestic focus with recognition of role in } \\
\text { international fora }\end{array}$ \\
\hline Italy & $\begin{array}{l}\text { SDGs are mapped on to National Strategic Goals. SDG } 12 \text { is } \\
\text { related to policies on biodiversity, sustainable management } \\
\text { of natural resources, protection of cultural heritage, mini- } \\
\text { mising pollution, 'promoting industrialisation domestically } \\
\text { and industrial share in developed countries', promoting cor- } \\
\text { porate social and environmental responsibility, sustainable } \\
\text { tourism, reducing waste, sustainable food production and } \\
\text { supply chains, increasing energy efficiency and renewables }\end{array}$ & Domestic focus \\
\hline Russian Federation & $\begin{array}{l}\text { No specific consideration of meeting of SDG } 12 \text {. Sustainable } \\
\text { development strategy in progress. Recognition of role as } \\
\text { 'global contributor' of energy and natural resources }\end{array}$ & - \\
\hline China & $\begin{array}{l}\text { Focus on China's role in global production and consumption } \\
\text { and its environmental impacts with reference to 'green' } \\
\text { national legislation and policy }\end{array}$ & $\begin{array}{l}\text { Recognition of domestic consumption and production and } \\
\text { global trade }\end{array}$ \\
\hline India & $\begin{array}{l}\text { Mapped to government and sub-national strategies. Report of } \\
2017 \text { did not consider SDG } 12\end{array}$ & - \\
\hline United States & $\begin{array}{l}\text { No recent strategy or review. Previously linked to domestic } \\
\text { policies on sustainable manufacturing, energy, water qual- } \\
\text { ity, sustainable agriculture and ecosystems with domestic } \\
\text { and international focus. International programmes and } \\
\text { agencies promoting sustainable development and consump- } \\
\text { tion, e.g. Asia-Pacific Partnership on Clean Development } \\
\text { and Climate, assistance and aid, partnerships with develop- } \\
\text { ing countries }\end{array}$ & - \\
\hline Canada & $\begin{array}{l}\text { SDG } 12 \text { is linked to the Government's Clean Growth } \\
\text { Strategy, public procurement, sustainable forestry, mining, } \\
\text { chemical and hazardous waste management policies, zero } \\
\text { waste and circular economy strategies and strategies for cit- } \\
\text { ies. The global perspective is referred to in relation to G7, } \\
\text { G20, OECD and other international commitments }\end{array}$ & Domestic and recognition of role in international fora \\
\hline
\end{tabular}

<https://ec.europa.eu/europeaid/policies/sustainable-development-goals_en>

HM Government, Industrial Strategy: Building a Britain fit for the future (2017)

The Federal Government, German Sustainable Development Strategy (2016) 
Table 2 (continued)

<https://www.gouvernement.fr/en/sustainable-development>

République France, Report on the Implementation by France of the Sustainable Development Goals (2016)

Italian Ministry for Environment, Land and Sea, Voluntary National Review Italy. National Sustainable Development Strategy (2017)

$<$ http://ac.gov.ru/en/events/015617.html>

Report on implementing the principles of sustainable development in the Russian Federation. Russian outlook on the new paradigm for sustainable development (Moscow 2012) <https://sustainabledevelopment.un.org/content/documents/1043natrepeng.pdf>

$<$ http://www.cn.undp.org/content/china/en/home/sustainable-development-goals/goal-12-responsible-consumption-and-production.html>

India, Voluntary National Review Report. On the implementation of Sustainable Development Goals (2017)

United States of America National Report. Transport, chemicals, waste management, mining and sustainable consumption and production (2010) <http://www.un.org/esa/dsd/dsd_aofw_ni/ni_pdfs/NationalReports/usa/Full_text.pdf>

Government of Canada, Canada's Implementation of the 2030 Agenda for Sustainable Development. Voluntary National Review (2018)

process of manufactured goods is complex; where environmental laws are being contravened, producers and suppliers may actively conspire to shield corruption and illegal resource extraction from view. Whilst EU Member States have to submit reporting and undergo monitoring by the EU Commission to ensure they are implementing the EU's Renewable Energy Directive, including its sustainability criteria, its oversight of the production conditions in exporting countries is less intensive (Lydgate 2012b).

Further, the introduction of environmentally motivated regulatory requirements (such as EU biofuels sustainability criteria) complicates the free movement of goods and services. The EU's practice of conditioning imports on meeting regulatory criteria that intrude deep into foreign production processes has been criticised as a strategy to protect domestic producers from cheaper imported products, or 'green protectionism', in the area of biofuels and beyond (Erixon 2012). In the context of ongoing Doha 'development' Round negotiations of the WTO, as well as international environmental negotiations dating back to the 1972 Stockholm Convention, developing countries have consistently raised concerns that attempts to apply domestic regulatory requirements to impose environmental or social welfare criteria that govern the way that products are produced infringes upon economic self-determination (Lydgate 2018). ${ }^{2}$

As well as EU regulatory restriction, the private sector has developed approaches to limit environmental harms. An examination of initiatives focused on the private sector is beyond the scope of this article, but bears brief consideration here as reliance on voluntary, market-driven approaches has also formed a component of some countries' SDG strategies. As noted above, Germany has made indicator-specific commitments to implementing the SDGs which constitute one of the most robust approaches within the EU. With respect to

\footnotetext{
${ }^{2}$ Note that this issue has also arisen consistently in major international environmental negotiations, such as during the Earth Summit and (more recently) the Rio +20 negotiations..
}

SDG 12, its targets include a commitment for 34 per cent of products to be certified by independent sustainability labelling schemes by 2030 (German Federal Government 2016). As this requirement will presumably encompass imported products as well, it comprises a transboundary approach. Yet voluntary labelling schemes are not comprehensive in their coverage.

In this case, to respond to concerns about rampant deforestation, as well as human rights abuses, consortia of stakeholders, such as NGOs, palm oil producers, and government representatives, have formed sustainability certification schemes including the Round Table on Sustainable Palm Oil ('RSPO'). In 2017, 20 per cent of palm oil was certified as sustainable (Carlson et al. 2018). Increasing the percentage of certified palm oil would aid in reducing negative transboundary impacts. However, a recent study showed that this voluntary, private-sector driven approach in itself was insufficient to lessen the development of peatland in the absence of monitoring and regulatory restrictions (Carlson et al. 2018).

\section{FTAs}

Since 2008, the EU has included sustainable development chapters in its trade agreements, which pertain directly to transboundary supply chains as they set out commitments for all Parties not to weaken environmental and labour protection in order to benefit trade and investment (Berger et al. 2017). As EU FTAs concern only those states party to the agreement, they provide a more targeted opportunity to pursue harmonisation and cooperation on environmental protection goals than does the multilateral forum of the WTO. The EU has adopted an approach often characterised as 'soft' or 'cooperative', as it focuses on facilitating and formalising dialogue between governments and civil society. For example, though such agreements call upon countries to enforce their environmental laws, if one party claims another has derogated from its environmental laws, this cannot be pursued through the main dispute settlement mechanism of the 
agreements. These limitations reflect that the overarching aim of these agreements is to facilitate trade (Marx et al. 2016). If located in the wider context of the trade $v$ environment debate, the EU's soft approach can also be seen as responding to a core concern that the imposition of binding sustainable development commitments through bi/multilateral trade agreements will frustrate the ability to conclude FTAs, particularly with developing states, as such requirements will be perceived as excessively intrusive (Ellison 2014). This charge cannot be levied against the EU's facilitative sustainable development chapters. But the example also highlights the limits to which the law can affect change without a corresponding political desire to see the expansion of international trade coupled with a genuine commitment to ensuring that that trade has a minimal environmental impact.

Given the identified gaps in information and reporting, an approach that is potentially more broadlyuseful to assessing transboundary environmental harm is the EU's practice of Sustainability Impact Assessment (SIA) of FTAs. The objective of SIA is to enable negotiators to agree 'better' FTAs. It does so by providing negotiators with information, comprising both expert analysis and extensive stakeholder engagement, about the likely impacts of the proposed agreement, thereby enabling them to make optimal decisions regarding trade-offs between different policy objectives (European Commission 2016). SIA in its current form is far too limited in scope to support the full achievement of SDG 12. The reason for this is twofold. First, the SIA is only concerned with the specific provisions of the FTA in question; not the impacts of a state's wider trade and non-trade policy framework. It will therefore fail to take account of other factors that affect the resource-efficiency of traded products. Second, an SIA will only cover forecasted impacts of increased trade within and between parties to the FTA. Impacts in third party countries, even those that are a direct consequence of the FTA, will not be addressed. A useful illustration of this is provided by the EU's SIA on CETA, the trade agreement between the EU and Canada:

Regarding nickel, aluminium and lead products, the EU will substitute decreasing Canadian production of these materials with imports from third countries... Therefore, in these countries, the CETA will contribute to accelerated depletion of metal mineral resources in addition to water and air pollution due to the highly polluting production processes for these materials. (Kirkpatrick et al. 2011, p 204).

Little consideration is given in the SIA to how these environmental impacts in third countries might be mitigated. Had these impacts been identified in either the EU or Canada, the EU's SIA framework would have required mitigation measures to be identified by the SIA consultants so that they could be considered for inclusion in the final agreement. There is clearly a need for SIA-style analysis of trade impacts to take place on a broader and more comprehensive scale. This would also respond to another core, but opposing concern, in trade $\mathrm{v}$ environment discourse to that set out above, namely that sustainable development discourse has resulted in the environment being neglected in the formulation of trade policy (Ross-Robertson 2003).

\section{Espoo Convention/Kyiv Protocol}

The Stockholm Declaration, one of the founding instruments of modern international environmental law, recommends that countries prevent transboundary harm by agreeing international conventions to undertake transboundary impact assessment (Stockholm Declaration 1972, Principle $21)$. The EU has fulfilled this commitment through both its internal environmental assessment legislation and its commitment to the 1991 UNECE Convention on Environmental Impact Assessment (the Espoo Convention 1991); EU Member States form the majority of participants. This requires states to notify others if certain types of actions may affect them (Article 3) and then, after conducting an environmental impact assessment, enter consultations with potentially impacted states. These consultations may relate to alternatives to the proposed activity, mitigation measures, monitoring of impacts and providing support to affected states in dealing with any impacts (Article 5).

EU countries have deepened this commitment through the 2003 Strategic Environmental Assessment Protocol encompassing EU and Eastern European Partnership countries which obligates them to undertake strategic environmental assessment of their 'plans and programmes', including their transboundary impacts (Kyiv Protocol 2003, Article 10). In both cases, the coverage excludes the assessment of trade policies. In practice, the utilisation of both treaties has been limited. The most recent Meeting of Parties of Espoo, for example, noted that there was no standardised approach to organising transboundary consultations and only a minority of Parties included in legislation the obligation to provide information to concerned Parties (UNECE 2013-15).

\section{International environmental law: limits of the obligation to prevent transboundary harm}

The obligation to prevent transboundary harm has been described as 'the cornerstone of international environmental law' (Sands 1995, p. 186), and is widely recognised as a customary norm of international law. It includes a duty to prevent, reduce and control environmental harm resulting from activities within a state's control, and a duty to cooperate in mitigating transboundary environmental risk through notification, consultation, and in some cases, environmental impact assessment (Birnie et al. 2009, p 137). 
It should be noted that the label of 'no harm' is somewhat misleading. States are not prohibited from taking or permitting actions that harm the environment outside their borders. Rather, these rules amount to an obligation of due diligence, i.e. states are required to take reasonable steps to prevent such harm (Knox 2002, p 293). This suggests an obligation for EU to take reasonable steps to ensure that its domestic consumption is not degrading the environments of other countries, rather than to prevent such actions altogether.

In international disputes, findings of transboundary harm have focused primarily on cross-border contamination, such as water or air-borne pollution (International Court of Justice (ICJ) 2010 or environmental degradation in contested territory (ICJ 2018), rather than harm resulting from supply chains. However, the expansion of international trade means that transboundary impacts have become more widespread and complex than ever before. This suggests the need for greater formal recognition that the 'no harm' obligation should also apply here. For example, that the EU, in its CETA SIA, identified likely negative impacts in other states as a result of its trade policy but has not taken steps to mitigate these suggests that they have fallen below the requisite standard of preventing transboundary harm.

As well as contravening this obligation, this approach is contrary to one of the basic principles of environmental justice, that the costs and benefits of environmental harms are distributed fairly across society, in this case the global society (Schlosberg 2007, chapter 2). Issues of responsibility and fair distribution have proven contentious throughout the history of environmental treaty-making (Mickelson 2015), and are particularly vexed in this context. The law of state responsibility requires that the state in which the harm originated bears the responsibility to redress this harm. In this instance, redressing an environmental harm could be achieved through restricting trade, or imposing additional onerous regulatory restrictions, that would hamper the development of export markets. Such solutions bring into conflict the economic development and environmental conservation 'pillars' of sustainable development. Regulatory oversight by states of foreign natural resource management also risks violating the principle of permanent sovereignty over natural resources, i.e. the right of states to freely determine how they utilise resources found within their jurisdiction (although see recent decisions that suggest that this right is now qualified by an obligation of sustainable use, for example Court of Arbitration 2013, para. 111-112). Expanding regulatory requirement to trace the impacts of trade on environmental protection is also likely to prove costly and complex, and risks coming into conflict with legal obligations imposed by the World Trade Organization and FTAs, including the foundational non-discrimination principle of treating products evenly, with respect to regulation, regardless of origin (Lydgate 2018).

\section{Preventing environmental harm through supply chains: addressing the gaps}

Methodologically, current assessment of transboundary trade impacts only applies in a narrow set of situations, as identified above. These are supplemented by MEAs that restrict trade for a narrow set of purposes, such as controlling the movement of extremely harmful products under the Basel Convention on the Control of Transboundary Movement of Hazardous Wastes and their Disposal (Basel Convention), and protecting species threatened with extinction by international trade under the Convention on International Trade in Endangered Species (CITES).

This leaves a large gap. However, a cross-cutting theme of this analysis is the concern that strengthening obligations to prevent environmental harm on a transboundary basis will infringe upon sovereignty or restrict economic development in exporting countries. There is certainly scope for progress in a way that circumvents these political concerns.

First, there is ample room for improvement simply through pursuing, and making accessible, more information about the international impacts of trade. One obvious way to do this is to include transboundary impacts in SDG 12 reporting. Given the complexity of global supply chains, simply understanding potential impacts of changing trade patterns is not always straightforward. Whilst various actors aim to document these impacts, adopting a systematicapproach of national reporting would greatly further these efforts. Alarmingly, the 2018 High-Level Political Forum report on SDG 12 noted that it is the 'least resourced' of all of the SDGs (HLPF 2018, p. 3). Further funding would help with the development of more effective assessment of transboundary impacts.

Second, the EU has developed procedural mechanisms, notably SIA, that aim to further understanding of how trade impacts upon other dimensions of sustainable development. That it concerns impacts in all states party to an FTA, not just those internal to the EU, means that SIA has the potential to provide a transboundary perspective on the implementation of both SDG 12 and the wider SDG agenda. Building on the EU approach to stakeholder engagement under SIA would be a positive first step in this regard.

EU Member States also participate in the Espoo Convention and its SEA Protocol, which require impact assessment of transboundary harms that may result from certain projects, plans and programmes. Like SIA, SEA and EIA have also been subject to criticism for neglecting to require mitigation measures to respond to harms. The Espoo Convention, for example, only requires that 'due account' is taken of the environmental impact assessment and the 
results of the consultations (Article 6). This is one of the main criticisms of environmental assessment generally (Holder 2004, p 235), and has been noted in relation to international environmental impact assessment specifically (Craik 2008, p 72-73).

However, culture theories of environmental assessment suggest that by requiring decision-makers to systematically consider the environmental impacts of proposed projects and policies, environmental assessment obligations will, over time, achieve an ecologisation of the institutions responsible for environmental decision-making (Bartlett 2005). It is possible to see environmental impact assessment as an institutional learning process. That is, consideration of the environment will become self-evidently necessary without the need for legislative prompts. Improved EIA therefore has the potential to deliver a gradual shift towards a more environmentally aware trade practice. Ultimately, this can bring about a better balance between the environmental, social welfare and economic development pillars of sustainable development. Providing development assistance for countries to conduct domestic environmental impact assessment is an approach that the EU is currently pursuing with its Eastern European Partnership countries in the framework of the Espoo Convention, and which could be expanded.

Notification and consultation are not the only obligations that could be imposed on negotiating states. It is possible to go further and argue that states must not only be required to consult on mitigatory measures but implement such measures. It is of course hoped that some form of mitigation is pursued following consultation, but it should be noted that few impact assessment regimes impose substantive obligations to mitigate potential negative impacts. An obligation to consult should not be conflated with an obligation to respond. In the context of a transboundary approach, however, there are advantages to limiting obligations to notification and consultation only. This would go some way in answering concerns about potential violation of the 'no harm' rule, and also provide countries the opportunity to adopt their own mitigatory measures, without imposing any burden that may fatally frustrate a cooperative approach to SDG 12 implementation.

These recommendations have some relevance to the broader goal of transformative SDG implementation, as they address overall gaps in rigorous use of targets and reporting, addressing interactions between goals, and thinking of the goals on a global, transboundary basis, rather than simply as domestic objectives. Yet ultimately, the manner through which SDG 12 will be implemented is a political decision for states and the success of the SDG agenda relies as much on a wider cultural shift away from excessive consumption patterns as it does on technical legal reform.

\section{Conclusion}

The failure to account for transboundary environmental harm in the SDG 12 context has a troubling implication with respect to the balance between the pillars of sustainable development: environmental concerns remain subordinate to the imperative of increasing free trade. Assessing trade policies in terms of their environmental, rather than economic, impacts will be necessary to fully redress this shortcoming and its implied hierarchy between the pillars. Trade has complex impacts and implications, and taking account of them necessarily involves considering the relationships between different, at times competing, but equally legitimate goals, a balancing process that can be approached through policy tools including impact assessment. Here we have argued that approaches which require the imposition of additional trade restrictions are politically unpalatable as they hamper export markets, thus pitting 'environment' and 'development' against one another. Instead, we have focused on the importance of more, and better, information to make transparent transboundary environmental harm through trade: information to bring about transformation.

Acknowledgements Invaluable research assistance was provided by Bushra Shaikh and Chloe Anthony. We are grateful to Donald McGillivray for helpful comments on an earlier draft of this article, and further suggestions from Bonnie Holligan, Emanuela Orlando, Helena Howe and Helen Dancer.

Open Access This article is distributed under the terms of the Creative Commons Attribution 4.0 International License (http://creativeco mmons.org/licenses/by/4.0/), which permits unrestricted use, distribution, and reproduction in any medium, provided you give appropriate credit to the original author(s) and the source, provide a link to the Creative Commons license, and indicate if changes were made.

\section{References}

Bartlett RV (2005) Ecological reason in administration: environmental impact assessment and green politics. In: Paehlke R, Torgerson D (eds) Managing Leviathan: environmental politics and the administrative state. Broadview Press, Peterborough

BBC News. Orangutan survival and the shopping trolley. Panorama. http://news.bbc.co.uk/panorama/hi/front_page/newsid_85230 00/8523999.stm. Accessed 22 Feb 2010

Beckerman W (1994) Sustainable development: is it a useful concept? Environ Values 3:191

Berger et al (2017) Towards greening trade? Tracking environmental provisions in the preferential trade agreements of emerging markets. Discussion Paper 2/2017, German Development Institute

Bertelsmann Stiftung, Sustainable Development Solutions Network (2018) Global responsibilities: implementing the goals. SDG index and dashboards report 2018

Birnie P, Boyle A, Redgwell C (2009) International law \& the environment. Oxford University Press, Oxford 
Bodle R, Lena D, Duwe M (2016) The Paris agreement: analysis, assessment and outlook. Carbon \& Climate Law Review 10(1):5-22

Carlson KM et al (2018) Effect of oil palm sustainability certification on deforestation and fire in Indonesia. PNAS 115:1-121

CBD (2002) Decision VI/26. Strategic plan for the convention on biological diversity, UNEP/CBD/COP/VI/26

CBD Decision (2010) Decision X/2. The strategic plan for biodiversity 2011-2020 and the Aichi Biodiversity Targets. UNEP/CBD/COP/ $\mathrm{DEC} / \mathrm{X} / 2$

Convention on Biological Diversity (1992) Rio de Janeiro, 5 June 1992, in force 29 December 1993, 31 ILM 822

Convention on Environmental Impact Assessment in a Transboundary Context (Espoo) (1991) 25 February 1991, in force 10 September 1997, 30 ILM 802

Court of Arbitration (2013) Indus Waters Kishenganga Arbitration (Pakistan v India), Final Award of the Court of Arbitration

Craik N (2008) The international law of environmental impact assessment: process, substance and integration. Cambridge University Press, Cambridge

Dawkins E et al (2016) Tracking Germany's Biomass Consumption: scientific Underpinning for the Implementation of the 2030 Agenda. Institute for Advanced Sustainability Studies, Potsdam

Doelle M (2016) The Paris agreement: historic breakthrough or high stakes experiment? Clim Law 6:1-20

Ellison K (2014) Rio + 20: how the tension between developing and developed countries influenced sustainable development efforts. Glob Bus Dev Law 27:107-129

Erixon F (2012) The rising trend of green protectionism: biofuels and the European Union, ECIPE. http://ecipe.org/publications/ rising-trend-green-protectionism-biofuels-and-european-union/. Accessed 5 July 2019

EU Directive 2009/28/EC on the promotion of the use of energy from renewable sources, L 140/16

European Commission (2016) Handbook for trade sustainability impact assessment. 2nd edition, European Union

Government of Canada (2018) Canada's Implementation of the 2030 Agenda for Sustainable Development. Voluntary National Review

German Federal Government (2016) German Sustainable Development Strategy. Available at: https://www.bundesregierung.de/resou rce/blob/997532/188836/7d1716e5d5576bec62c9d16ca908e8 0e/2017-06-20-nachhaltigkeit-neuauflage-engl-data.pdf?downl $\mathrm{oad}=1$. Accessed 20 Apr 2019

Guardian (2016) Korean palm oil firm accused of illegal forest burning in Indonesia. Available at: https://www.theguardian.com/ environment/2016/sep/01/korean-palm-oil-firm-accused-of-illeg al-forest-burning-in-indonesia. Accessed 5 July 2019

High Level Political Forum on Sustainable Development (2018) HLPF Review of SDGs implementation: SDG 12-ensure sustainable consumption and production patterns, 1-7. https://sustainabledeve lopment.un.org/content/documents/196532018backgroundnotesS DG12.pdf

Holder J (2004) Environmental assessment: the regulation of decision making. Oxford University Press, Oxford

Intergovernmental Panel on Climate Change (2018) Global warming of $1.5^{\circ} \mathrm{C}$ (World Meteorological Organization/United Nations Environment Programme)

International Court of Justice (2010) Pulp mills on the River Uruguay (Argentina v. Uruguay). https://www.icj-cij.org/en/case/135. Accessed 20 Apr 2010

International Court of Justice (2018) Maritime delimitation in the Caribbean Sea and the Pacific Ocean (Costa Rica v. Nicaragua). https ://www.icj-cij.org/en/case/157. Accessed 2 Feb 2018

Kew RBG (2016) The state of the world's plants report-2016. Royal Botanic Gardens, Kew
Kirkpatrick C et al (2011) A trade SIA relating to the negotiation of a comprehensive economic trade agreement (CETA) between the EU and Canada' (Final Report, Trade 10/B3/B06)

Knox J (2002) The myth and reality of transboundary environmental impact assessment. AJIL 96:2-291

Kokott J (2007) States, sovereign equality. Max Planck Encyclopaedia of Public International Law, Oxford Public International Law: https://www.opil.ouplaw.com). Accessed 20 Apr 2019

Kotzé LJ, French D (2018) The anthropocentric ontology of international environmental law and the sustainable development goals: toward an ecocentric rule of law in the anthropocene. Glob J Comp Law 7:5-36

Lydgate E (2012a) Sustainable development in the WTO: from mutual supportiveness to balancing. World Trade Rev 11:621-639

Lydgate E (2012b) Biofuels, sustainability and trade-related regulatory chill. J Int Econ Law 15(1):157-180

Lydgate E (2018) Terms of trade: environment. In: Dingwerth Klaus, Weinhardt Clara (eds) The language of world trade politics: unpacking the terms of trade. Routledge, New York

Marx A et al (2016) Dispute settlement in the trade and sustainable development chapters of EU trade agreements. Leuven Centre for Global Governance Studies, pp. 1-102

Material flow accounts statistics: Material Footprints, Eurostat (2018). Available at: https://ec.europa.eu/eurostat/statisticsexplained/ index.php?title=Material_flow_accounts_statistics_-_material_ footprints\#Accounting_for_trade_flows_in_terms_of_raw_mater ials_equivalents. Accessed 5 July 2019

Mickelson (2015) The Stockholm Conference and the Creation of the North-South Divide in International Environmental Law and Policy. In: Mickelson et al. International Environmental Law and the Global South. Cambridge University Press 2015

Millennium Development Goals (2000) A/RES/55/2, para. 5

O'Connor D et al (2016) Universality, integration, and policy coherence for sustainable development: early SDG implementation in selected OECD countries. Working Paper. Washington, DC: World Resources Institute. http://www.wri.org/publication/unive rsality_integration_and_policy_coherence. Accessed 5 July 2019

Office of National Statistics (2017) United Kingdom, https://www.ons. gov.uk/economy/environmentalaccounts/articles/sustainabledeve lopmentgoalstakingstockprogressandpossibilities/november 20 17\#global-indicators. Accessed 5 July 2019

Pardy B (2005) In search of the holy grail in environmental Law: a rule to solve the problem. McGill Int J Sustain Dev Law Policy 1(1):29

Ross-Robertson A (2003) Is the environment getting squeezed out of sustainable development? Public Law, pp 249-259

Sands P (1995) Principles of International Environmental Law. Cambridge University Press, Cambridge

Schlosberg D (2007) Defining environmental justice: theories, movements, and nature. Oxford University Press, Oxford

SDG Knowledge Platform (2018). https://sustainabledevelopment.un. org/sdg 12. Accessed 5 July 2019

Secretariat to the Convention on Biological Diversity (2014) Global Biodiversity Outlook 4. Montreal

Stockholm Declaration of the United Nations Conference on the Human Environment (1972) UN Doc.A/CONF/48/14/REV.1

Stone CD (1994) Deciphering sustainable development. Chic Kent Law Rev 69:977

Kyiv Protocol on Strategic Environmental Assessment (2003) https ://www.unece.org/fileadmin/DAM/env/eia/documents/legaltexts /protocolenglish.pdfSwedish

UNECE Implementation of the Convention on Environmental Impact Assessment in a Transboundary Context (2013-15). Fifth review (2017) ECE/MP.EIA/25

UNEP/International Resources Panel (2015) International trade in resources a biophysicalassessment 
UNEP/International Resources Panel (2017) Assessing global resource use: a systems approach to resource efficiency and pollution reduction

United Nations (2015) Transforming our world: the 2030 Agenda for Sustainable Development, UN General Assembly Resolution A/ RES/70/1, 21 October 2015

United Nations (2017) Department of economic and social affairs, United Nations, 2017 Voluntary National Reviews: Synthesis Report, pp 12

United Nations Statistics Division (2018). https://unstats.un.org/sdgs/ report/2018/goal-12/

Voight $\mathrm{M}$ et al (2018) Global demand for natural resources eliminated more Than 100,000 Bornean Orangutans. Curr Biol 28(5):761

Wiedmann T, Lenzen M (2018) Environmental and social footprints of international trade. Nat Geosci 11:314-321

Wiedmann $\mathrm{O}$ et al (2015) The material footprint of nations. PNAS 112:20-6271
World Commission on Environment and Development (1987) Our common future. Oxford University Press, Oxford

World Resources Institute (2018) Forests and landscapes in Indonesia. https://www.wri.org/our-work/project/forests-and-landscapes -indonesia/climate-change-indonesia. Accessed 5 July 2019

World Summit on Sustainable Development (2002) Johannesburg

World Trade Organization RTA list (2019). https://www.wto.org/engli sh/tratop_e/region_e/regfac_e.htm. Accessed 5 July 2019

WWF/ZSL (2016) Living Planet Report 2016: risk and resilience in a new era. WWF International

Publisher's Note Springer Nature remains neutral with regard to jurisdictional claims in published maps and institutional affiliations. 